\title{
Chondroitin Sulfate Impairs Neural Stem Cell Migration Through ROCK Activation
}

\author{
Layla T. Galindo ${ }^{1}$ • Mayara T. V. V. Mundim ${ }^{1} \cdot$ Agnes S. Pinto $^{1}$ • \\ Gabrielly M. D. Chiarantin ${ }^{1}$ • Maíra E. S. Almeida ${ }^{2}$ • Marcelo L. Lamers ${ }^{3}$ • \\ Alan R. Horwitz ${ }^{4}$ - Marinilce F. Santos ${ }^{5} \cdot$ Marimelia Porcionatto $^{1}$ (D)
}

Received: 20 January 2017 / Accepted: 19 April 2017 /Published online: 5 May 2017

(C) The Author(s) 2017. This article is an open access publication

\begin{abstract}
Brain injuries such as trauma and stroke lead to glial scar formation by reactive astrocytes which produce and secret axonal outgrowth inhibitors. Chondroitin sulfate proteoglycans (CSPG) constitute a well-known class of extracellular matrix molecules produced at the glial scar and cause growth cone collapse. The CSPG glycosaminoglycan side chains composed of chondroitin sulfate (CS) are responsible for its inhibitory activity on neurite outgrowth and are dependent on RhoA activation. Here, we hypothesize that CSPG also impairs neural stem cell migration inhibiting their penetration into an injury site. We show that DCX+ neuroblasts do not penetrate a CSPG-rich injured area probably due to Nogo receptor activation and RhoA/ROCK signaling pathway as we demonstrate in vitro with neural stem cells cultured as neurospheres and pull-down for RhoA. Furthermore, CSimpaired cell migration in vitro induced the formation of large
\end{abstract}

Electronic supplementary material The online version of this article (doi:10.1007/s12035-017-0565-8) contains supplementary material, which is available to authorized users.

Marimelia Porcionatto

marimelia.porcionatto@unifesp.br

1 Department of Biochemistry, Laboratory of Neurobiology, Universidade Federal de São Paulo, Rua Pedro de Toledo, 669 - 3o andar, São Paulo, SP 04039-032, Brazil

2 Physiopathology Laboratory, Butantan Institute, São Paulo 05503-900, Brazil

3 Department of Morphological Sciences, Universidade Federal do Rio Grande do Sul, Porto Alegre 90050-170, Brazil

4 Department of Cell Biology, University of Virginia School of Medicine, Charlottesville 22903, USA

5 Department of Cell and Developmental Biology, Biomedical Sciences Institute, Universidade de São Paulo, São Paulo 05508-000, Brazil mature adhesions and altered cell protrusion dynamics. ROCK inhibition restored migration in vitro as well as decreased adhesion size.

Keywords Neural stem cell $\cdot$ Cell migration $\cdot$ Chondroitin sulfate $\cdot$ Traumatic brain injury $\cdot$ RhoA $\cdot$ Rock

\section{Introduction}

In the adult mammalian brain, neuroblasts from the subventricular zone (SVZ) travel through the rostral migratory stream towards the olfactory bulb, where they differentiate and integrate into the local circuitry [1-3]. Injury alters neurogenesis and stimulates neuroblast migration from the neurogenic niche to the injured area $[4,5]$. Interaction of neural stem cells (NSC) with extracellular matrix (ECM) components is critical for migration, and external stimuli are transduced into cytoskeletal rearrangements that influence neuroblast migration by the action of RhoGTPases [6].

After a trauma to the brain, injured neurons present a limited capacity to regenerate due to the formation of a glial scar, which acts as a barrier for axons and neurite regrowth [7]. Glial scars are produced mainly by reactive astrocytes, oligodendrocytes, and microglia. These cells produce axonal growth inhibitory molecules, such as chondroitin sulfate proteoglycans (CSPG), Nogo, myelin-associated glycoprotein (MAG), and oligodendrocyte-myelin glycoprotein (OMGp) [8]. CSPG comprise a heterogeneous class of proteoglycans that includes, in the brain, RPTP $\beta$, phosphacan, NG2, brevican, aggrecan, and neurocan. These membrane and ECM proteoglycans play important roles during CNS development, including control of axonal outgrowth and guidance $[9,10]$, directing neuronal precursor migration and regulating Purkinje cell differentiation and maturation in the developing 
cerebellum [11]. The CS side chains of CSPG are responsible for the inhibitory activity, and degradation of CS by the action of the bacterial enzyme chondroitinase $\mathrm{ABC}$ attenuates CSPG inhibitory activity and promotes axon regrowth [12-14]. Recent studies identified receptor protein tyrosine phosphatase sigma (RPTP $\sigma)$ and Nogo receptor family members (NgR) as CSPG receptors that act through binding to CS [15-17].

Inhibition of neurite outgrowth mediated by CSPG depends on RhoA activation [16, 18, 19], and RhoA regulates maturation of cell-matrix adhesions and cell contractility through activation of myosin II [20]. Cell adhesion, contractility, and signaling help to polarize migrating cells and allow directional motility. Integrins, paxillin, and FAK (focal adhesion kinase), among other proteins, generate the signals that regulate directed cell migration [21].

In light of the importance of CSPG/CS in axonal growth inhibition and RhoA activation $[8,19,22]$, we hypothesized that a similar mechanism may occur during neural stem cell adhesion and migration. Here, we report how CS regulates adult NSC migration in vitro, describing changes in protrusion formation and adhesion dynamics. Also, we suggest that these processes are mediated by RhoA/ROCK signaling.

\section{Material and Methods}

\section{Animals}

Adult male C57BL/6 mice used for all experiments were maintained under a $12 \mathrm{~h} \mathrm{light/dark} \mathrm{cycle} \mathrm{with} \mathrm{access} \mathrm{to} \mathrm{water}$ and food ad libitum. All experimental procedures and animal handling performed were approved by the Committee for Ethics in Research from Universidade Federal de São Paulo and University of Virginia Animal Care and Use Committee and followed international guidelines for care and use of experimental animals (http://www.iclas.org).

\section{TBI Model and Tissue Preparation}

Adult 12-week-old male C57BL/6 mice were anesthetized with intraperitoneal injection of ketamine chloridrate $(66 \mathrm{mg} / \mathrm{kg})$ and xylazine $(32 \mathrm{mg} / \mathrm{kg})$ mixture (Dopalen, Brazil). Traumatic brain injury (TBI) was performed according to previously described protocol [23]. Briefly, a metal needle was chilled by immersion on isopentane on dry ice and was inserted four times into mice motor cortex (stereotaxic coordinates from bregma: AP $+0.198 \mathrm{~mm}$; $\mathrm{ML}+0.175 \mathrm{~mm}$; DV $-0.15 \mathrm{~mm}$ ) [24]. Fourteen days later, mice were anesthetized and intracardially perfused with $4 \%$ paraformaldehyde (PFA) in $0.1 \mathrm{M}$ PBS. Brain was removed from skull, postfixed in $4 \%$ PFA overnight at $4{ }^{\circ} \mathrm{C}$, submersed in $30 \%$ sucrose at $4{ }^{\circ} \mathrm{C}$, and frozen using liquid nitrogen.
Cryostat coronal sections $(20 \mu \mathrm{m})$ were collected on silanized slides (Superfrost slides, Fisher Scientific, USA) and prepared for immunofluorescence staining for detection of CSPG and DCX (marker for neuroblasts).

\section{Neurosphere Assays and Transfection}

NSC were obtained from the SVZ of 6-week-old C57BL/6 mice and cultured as neurospheres as previously described [25]. Complete medium composition was DMEM:F12 1:1 (Gibco, USA), 2\% B27 supplement (Gibco), 20 ng/ml EGF (Sigma, USA), $20 \mathrm{ng} / \mathrm{ml}$ FGF2 (R\&D Systems, USA), 1\% penicillin/streptomycin (Gibco), and $5 \mu \mathrm{g} / \mathrm{ml}$ heparin (Sigma). Neurospheres were ready to passage when the majority of them was about $100-150 \mu \mathrm{m}$ in diameter [26]. Neurospheres were dissociated with trypsin and gently triturated to get single-cell suspension that was expanded as secondary spheres, used as single cells or used for nucleofection. Experiments were performed with cultures between passages 3 and 10 .

For migration assay, glass coverslips were covered with $10 \mu \mathrm{g} / \mathrm{ml}$ poly-L-lysine (Sigma) for $30 \mathrm{~min}$ at room temperature, washed three times with $0.1 \mathrm{M}$ PBS, dried on air, incubated with $50 \mu \mathrm{g} / \mathrm{ml}$ laminin (Sigma) for $30 \mathrm{~min}$ at $37^{\circ} \mathrm{C}$, washed with DMEM (Gibco), and finally incubated with $40 \mu \mathrm{g} / \mathrm{ml} \mathrm{CS}-A$ sodium salt from bovine trachea (Sigma) for $4 \mathrm{~h}$ at $37^{\circ} \mathrm{C}$ and washed with DMEM. All coverslips coated with CS were previously coated with laminin. Neurospheres were plated in complete medium, followed by incubation for 20 min at $37^{\circ} \mathrm{C}$ in a $\mathrm{CO}_{2}$ incubator (to allow cell adhesion) prior to the treatment with $10 \mu \mathrm{M}$ of ROCK inhibitor Y27632 (Santa Cruz, USA) or Nogo-66 (1-40) antagonist peptide (NEP1-40, Sigma). Migrated distance was defined as the extent of cell migration measured from the border of the neurosphere and the cell final position. Distance measurements were performed blind by an unbiased observer using ImageJ (http://rsbweb.nih.gov/ij/).

For total internal reflection fluorescence (TIRF) assay, neurospheres were dissociated and 3-5 $\times 10^{6}$ cells were nucleofected (Amaxa Biosystems, Germany) with $5 \mu \mathrm{g}$ of paxillin-GFP plasmid [27], according to the manufacturer's protocol (A-033) for adult neural stem cells. Immediately after nucleofection, cells were transferred to a 6 -well culture plate with pre-warmed complete medium and incubated at $37^{\circ} \mathrm{C}$ in a $\mathrm{CO}_{2}$ incubator for $24 \mathrm{~h}$.

\section{Pull-Down}

Active RhoA was measured using pull-down assay kit from Cytoskeleton (USA). Neurospheres were plated on laminin or laminin + CS precoated plates and $3 \mathrm{~h}$ after plating, neurospheres were washed with ice-cold PBS $0.1 \mathrm{M}$ followed by harvesting with $1 \times$ Cell Lysis Buffer supplemented 
with $1 \times$ Protease Inhibitor Cocktail. NSC protein extract $(240 \mu \mathrm{g})$ was incubated at $4{ }^{\circ} \mathrm{C}$ for $1 \mathrm{~h}$ with $50 \mu \mathrm{g}$ of rhotekin-RBD beads, which binds specifically to GTP-Rho protein. Bead samples were resuspended in $20 \mu \mathrm{L}$ Laemmli buffer. Total extract (15 $\mu \mathrm{g}$ ), His-Rho control protein (20 ng), and bead samples were subjected to SDS-PAGE (12\%) and transferred to a nitrocellulose membrane (GE Healthcare, UK). The membrane was blocked with 5\% BSA (SigmaAldrich, USA) in TBS-T (TBS, $0,01 \%$ Tween ${ }^{\circledR} 20$ ) at room temperature for $1 \mathrm{~h}$ and then incubated for $18 \mathrm{~h}$ at $4{ }^{\circ} \mathrm{C}$ with anti-RhoA monoclonal antibody (1:500, Cytoskeleton) or Bactin (1:10,000, Millipore, Germany). The nitrocellulose membrane was washed three times with TBS-T and subsequently hybridized with horseradish peroxidase-conjugated anti-mouse IgG (1:5000, Santa Cruz Biotechnology, EUA) at room temperature for $1 \mathrm{~h}$. After three washes with TBS-T, immune complexes were visualized by adding Luminata Forte Western HRP Substrate (Millipore, Germany) and chemiluminescent signal was acquired on Odyssey FC@ (LI-COR Biosciences, USA). Molecular size of immunoreactive bands was determined by Kaleidoscope prestained protein standards (Bio-Rad, USA).

\section{Microscopy}

Migration Speed and Protrusion Dynamics NSC as single cells were plated on laminin or laminin + CS glass-bottomed dishes in complete medium containing $25 \mathrm{mM}$ Hepes, allowed to adhere for $20 \mathrm{~min}$ at $37{ }^{\circ} \mathrm{C}$ in a $\mathrm{CO}_{2}$ incubator and imaged in an inverted phase contrast microscope (TE300; Nikon, Japan) equipped with $37^{\circ} \mathrm{C}$ heater and controlled by Metamorph software (Molecular Devices, USA). For migration speed and directionality, time-lapse images were obtained with a $\times 10$ objective at 5-min intervals for $18 \mathrm{~h}$ and each cell was individually tracked using ImageJ software. For protrusion dynamics, time-lapse images were acquired at $5 \mathrm{~s}$ during $30 \mathrm{~min}$, and for each protrusion, a line (5 pixels wide) was drawn along regions oriented in the protrusion direction and perpendicular to the lamellipodial edge. Protrusion parameters were quantified by kymograph [28], using ImageJ software. The results were plotted in a graph where the $Y$-axis is the distance reached by the lamellipodium along that line, and the $X$-axis is time.

Adhesion Dynamics NSC expressing paxillin-GFP were plated on laminin or laminin + CS. After 40 min, images were acquired on a Total Internal Reflectance Fluorescent (TIRF) microscope (Olympus IX70, 1.45 NA oil Olympus PlanApo 660 TIRFM objective) fitted with a Ludl modular automation controller (LudlEletronic Products, USA) and controlled by Metamorph. Paxillin-GFP was excited with a 488-nm laser line of an Argon laser (MellesGriot, USA), and images were acquired at 3 -s intervals for $8 \mathrm{~min}$ and analyzed using Image software. The leading edge was zoomed in (150\%) and the size of paxillin-positive adhesions within focal adhesion sites was measured when matured and before disassembly.

\section{Immunohistochemistry}

Fixed coronal brain sections, neurospheres, or single NSC were permeabilized with $0.1 \%$ Triton $\mathrm{X}-100$ for $10 \mathrm{~min}$, blocked with $5 \%$ fetal bovine serum in $0.1 \%$ Triton $\mathrm{X}-100$ for $1 \mathrm{~h}$ at room temperature, and then incubated with primary antibodies at $4{ }^{\circ} \mathrm{C}$ overnight. Incubation with the appropriate secondary antibodies or FITC-Phalloidin (1:200, Sigma) and DAPI (1:10,000, Molecular Probes, USA) was performed at room temperature for $1 \mathrm{~h}$. Glass slides were mounted using Fluoromount $\mathrm{G}$ mounting medium (Electron Microscopy Sciences, USA). Brain images were captured on a Leica TCS SP8 confocal microscopy using LASAF software (Leica, Germany), and NSC images were captured on an Olympus FluoView 300 confocal system using the FluoView software (Olympus, Japan).

Primary antibodies: mouse anti-CSPG (1:250, Abcam, USA); guinea pig anti-DCX (1:1000, Millipore, USA); chicken anti-GFAP (1:500, Abcam). Secondary Antibodies (Invitrogen, USA): Alexa Fluor 594-conjugated goat anti-mouse IgG (1:300); Alexa Fluor 488-conjugated goat anti-guinea pig IgG (1:1000); Alexa Fluor 488conjugated goat anti-chicken IgG (1:500).

\section{Statistical Analysis}

Data are presented as mean \pm SEM and analyzed using the unpaired Student's $t$ test by the use of Prism v5.0 software (GraphPad Software, USA). Statistical significance was set at $p<0.05$.

\section{Results}

\section{A CSPG-Rich Environment Impairs NSC Migration into the Injury Site}

Following injury, migratory DCX+ neuroblasts leave the SVZ niche located at the lateral ventricle wall and migrate towards the injury guided by chemokines, ECM components, and blood vessels [5, 29, 30]. To assess whether neuroblast migration into the CSPG-rich scar was impaired, we performed a TBI model to the adult murine motor cortex, and 2 weeks after TBI, DCX+ neuroblasts that migrated from the SVZ towards the injury were immunolocalized. DCX+ neuroblasts did not penetrate into the CSPG-rich injury site (Fig. 1), shown by immunostaining for CSPG core protein. As soon as the neuroblasts reach an area with high content of CSPG, cells pile up at the injury border and migrate around it. 

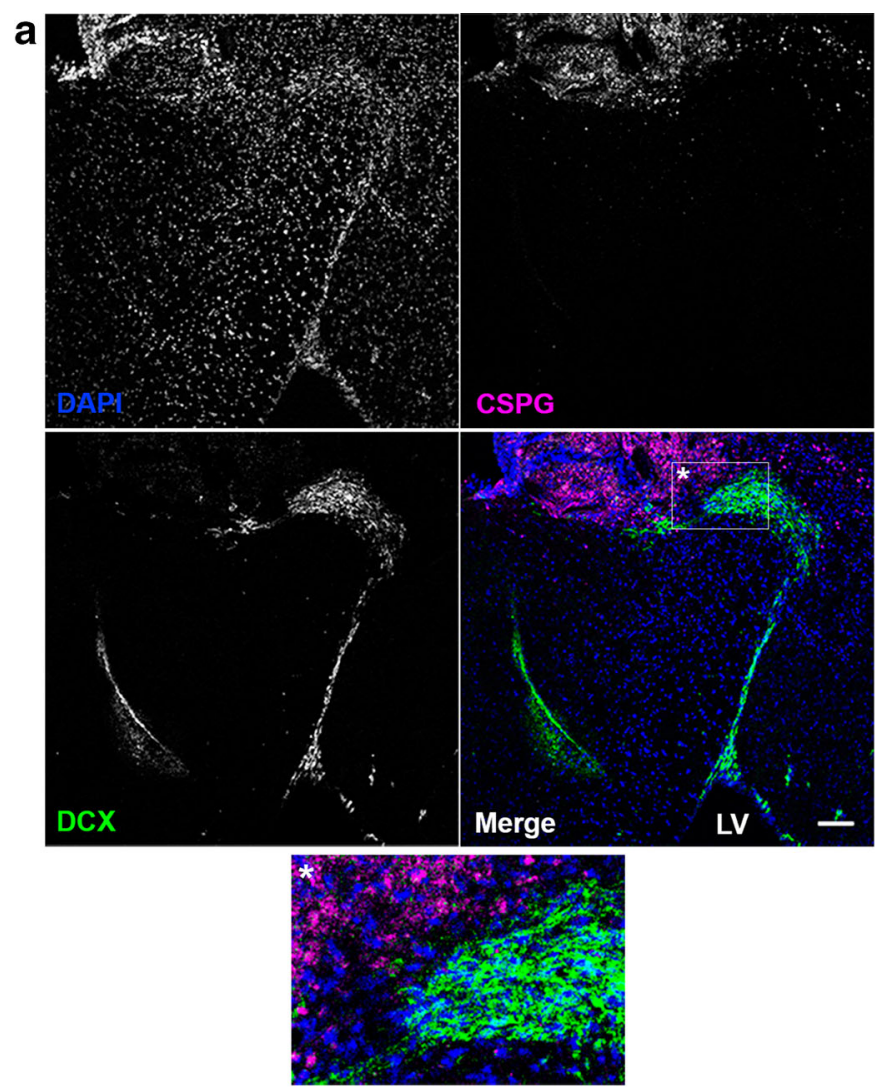

Fig. 1 CSPG impairs NSC penetration into the injury site after TBI and acts through NgR. a Two-week postinjury glial scar was already formed and NSC migration was evaluated. DCX+ neuroblasts (green) leave their niche at the lateral ventricle (LV) and migrate towards the injury site characterized by high expression of CSPG (magenta). NSC are prevented to enter the proteoglycan-rich regions, accumulate at the injury border, and migrate around this area (detail). Scale bar at $100 \mu \mathrm{m}$. b NSC cultured as neurospheres were plated on laminin $+\mathrm{CS}$ with or without the

To assess how CS impairs NSC migration in vitro, SVZderived NSC cultured as floating neurospheres were plated on laminin + CS, which induces an inhibitory substrate for neurite growth, and treated with NEP1-40, a Nogo-66(1-40) antagonist peptide which blocks signaling through Nogo receptor 1 (NgR1). $\mathrm{NgR} 1$ is implicated as a functional receptor for MAIs (myelin-associated inhibitors) [31,32] and recently characterized as receptor for CSPG expressed by neurons [15]. NSC derived from neurospheres plated on laminin + $\mathrm{CS}$ and treated with $10 \mu \mathrm{M}$ NEP1-40 migrated longer distances (average $180 \mu \mathrm{m}$ ) when compared to NSC plated on laminin + CS without NEP1-40 treatment (average $60 \mu \mathrm{m}$ ) (Fig. 1b). These data suggest $\mathrm{NgR} 1$ as a CS receptor which mediates impairment of NSC migration.

\section{CS Inhibits NSC Migration and Decreases Migration Speed In Vitro}

In order to elucidate how CS might influence NSC migration and to evaluate NSC migratory behavior in response to CS,
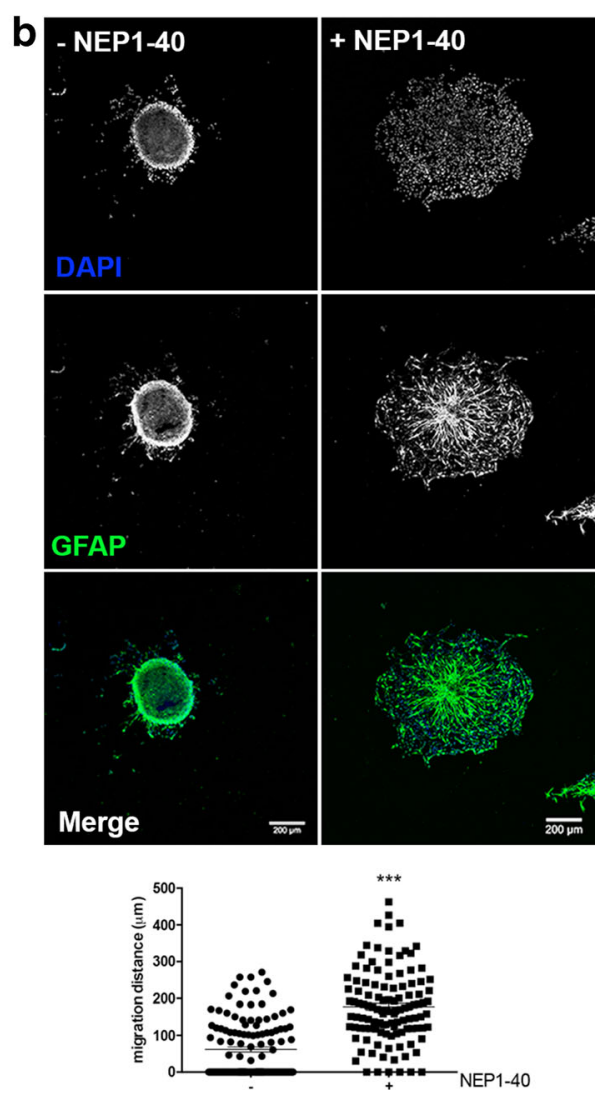

NgR inhibitor NEP1-40. CS inhibits NSC migration and decreases the distance traveled by the cells. In the presence of NEP1-40, NSC migrated longer distances $(p<0.0001)$, suggesting that the inhibition of migration promoted by CS is mediated by NgR. Data were collected $18 \mathrm{~h}$ after neurospheres were plated. Number of neurospheres analyzed: with NEP1-40 = 115; without NEP1-40 $=123$. NSC were immunolabeled with GFAP (green) and nuclei stained with DAPI. Scale bar at $200 \mu \mathrm{m}$ (Color figure online)

neurospheres were plated on laminin only, a permissive substrate, or on laminin + CS and measured migration distance and speed. When adhered to laminin, cells migrate out of the neurosphere, and in contrast, NSC migration was greatly inhibited when neurospheres were plated on laminin + CS in comparison to laminin alone (Fig. $2 \mathrm{a} ; p<0.0001$ ). Furthermore, all cells migrating from neurospheres plated on laminin + CS migrated less than $10 \mu \mathrm{m}$, whereas the average migration distance of cells plated on laminin was $100 \mu \mathrm{m}$. These results show the inhibitory properties of CS on NSC migration, corroborating with the in vivo results presented in Fig. 1.

Based on the observation that CS inhibited NSC migration in vivo and in vitro, we wondered whether $\mathrm{CS}$ also affected the speed of migrating cells. Neurospheres were dissociated and NSC were plated as single cells on laminin + CS covered glass bottom plates. Images were acquired at 5 -min intervals for $18 \mathrm{~h}$. NSC migrating on laminin + CS migrated less distance than those on laminin $(p=0.0230)$ (Fig. 2b, c) and moved significantly slower in the first hour (average speed 
a

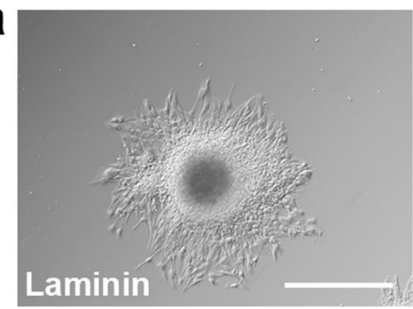

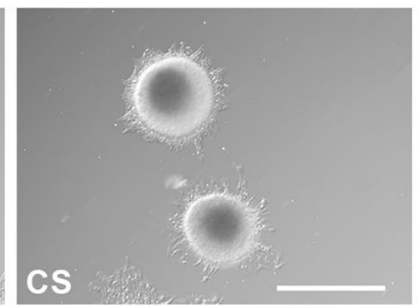

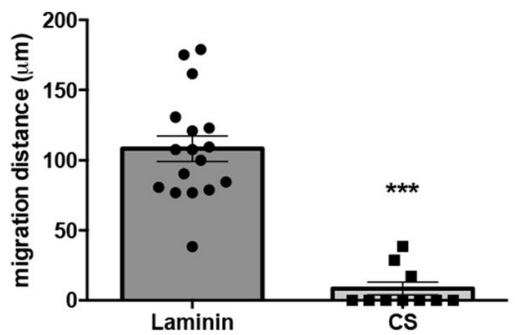

CS
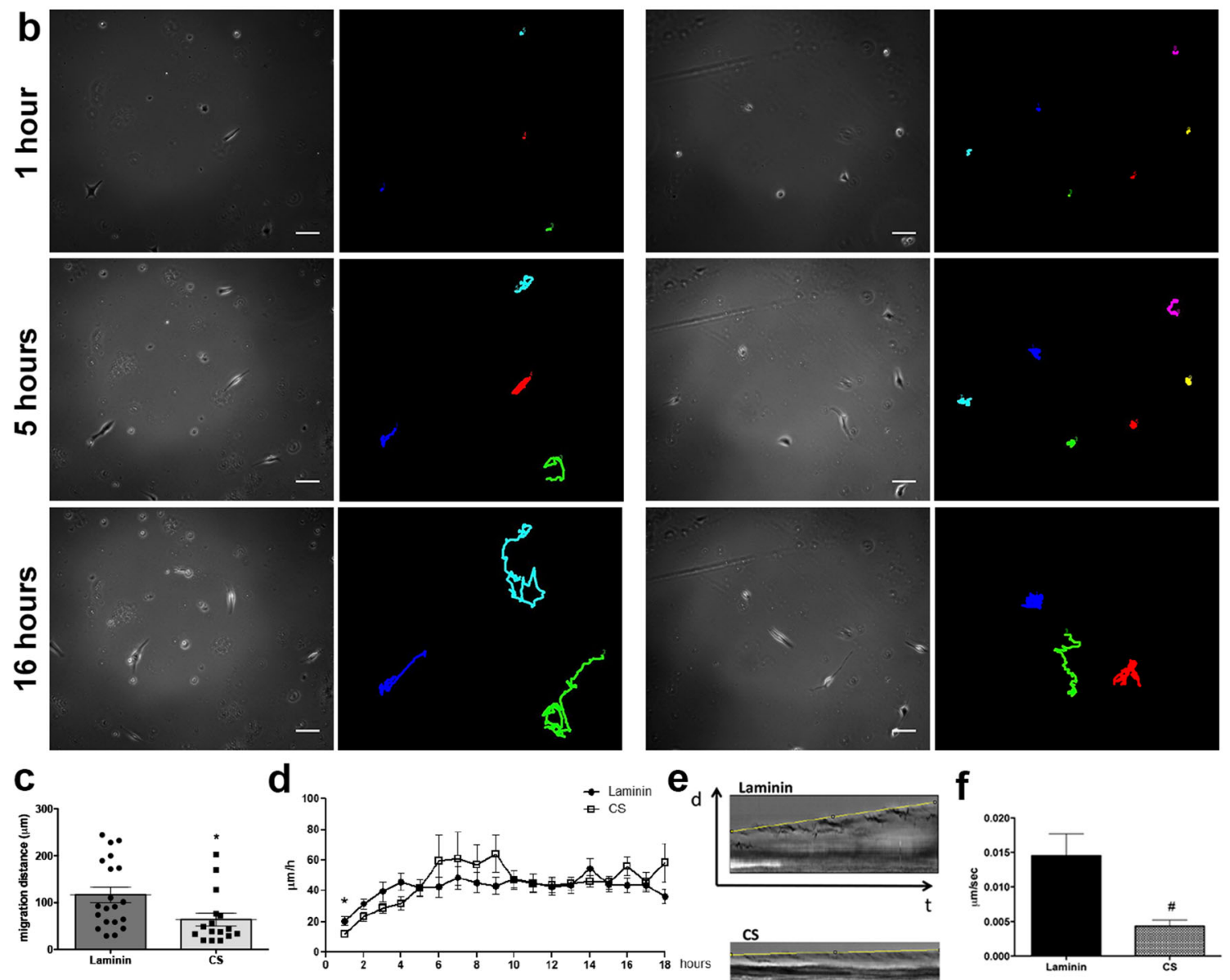

f

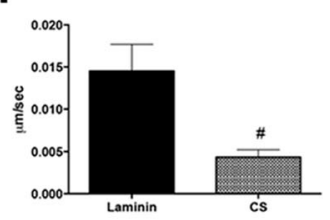

Fig. 2 CS inhibits NSC migration, decreases speed, and alters protrusion, and adhesion dynamics in vitro NSC cultured as neurospheres were plated on laminin or laminin + CS. a CS impairs NSC migration and decreases the distance traveled by the cells $(* * * p<0.0001)$. Data were collected $18 \mathrm{~h}$ after neurospheres were plated. Scale bar at $200 \mu \mathrm{m}$. Number of neurospheres analyzed: laminin $=17$; CS $=10$. $\mathbf{b}$ NSC were plated as single cells, and images were captured every $5 \mathrm{~min}$ for $18 \mathrm{~h}$. Cells are represented as dots and the migration routes as lines 1 and 5 and $16 \mathrm{~h}$ after start. Scale bar at $20 \mu \mathrm{m}$. c Quantification of migration from start to finish from NSC plated as single cells for $18 \mathrm{~h}$ represented on Fig. $2 \mathrm{~b}(* p=0.0230)$. Number of cells analyzed: laminin $=20 ; \mathrm{CS}=16$. $\mathbf{d}$ NSC average speed during $18 \mathrm{~h}$ of

$11.8 \mu \mathrm{m} / \mathrm{h} ; p=0.0181)$ when compared to cells plated on laminin (average speed $20.3 \mu \mathrm{m} / \mathrm{h}$ ). In the following hours, although not reaching statistical significance (hour 2 migration. NSC are significantly slower within the first hour of migration $\left({ }^{*} p=0.0181\right)$ and kept migrating lower over time although not reaching statistical significance. From the hours 6 to 9, cells migrated faster (not statistically significant) on laminin + CS than on laminin, and from hours $10-18$, migration speed was similar in both substrates. Number of cells analyzed: laminin $n=20$; CS $n=15$. e Kymographs of NSC plated on laminin and laminin + CS. Protrusion progressions are outlined by the yellow line. NSC protrusions on laminin $+\mathrm{CS}$ are nonproductive with no retraction or progression. $\mathbf{f N S C}$ protrusions formation speed is slower on CS $(\# p=0.0167)$. Number of protrusions analyzed: laminin $=22$; $\mathrm{CS}=17$. At least three independent movies were acquired for each condition. $d$ distance, $t$ time. Scale bar at $200 \mu \mathrm{m}$ (Color figure online)

$p=0.083$; hour $3 p=0.109$; hour $4 p=0.058$ ), the inhibitory effect of CS was consistent among experiments, as cells kept on moving slower on laminin $+\mathrm{CS}$ than on laminin (Fig. 2d 
and Online Resources 1 and 2), and there was an increase although not statistically significant, in migration speed of cells on laminin + CS up to $9 \mathrm{~h}$. From the tenth hour on, migration speed was equivalent on laminin + CS and on laminin, suggesting that CS inhibits the initiation of migration in vitro, and inhibition is not sustained for longer periods of time.

\section{CS Alters NSC Protrusion and Adhesion Dynamics}

Protrusion formation and adhesion dynamics are early migratory events. Following the observation that CS inhibits NSC migration and decreases migration speed in vitro, the question was whether CS would affect these key events in cell migration. The presence of CS in the substrate caused a 50\% decrease in the number of cells displaying three or more protrusions when compared to cells grown on laminin alone (data not shown), and the protrusions were more stable with increased ruffling. Kymography revealed that protrusions of NSC plated on laminin + CS exhibited no progression, and the speed of protrusion formation was significantly slower ( $p=0.0167)$ compared to protrusion formed by cells plated on laminin that induced persistent protrusion progression (Fig. 2e, f). These data suggest impairment on cell adhesion properties induced by CS.

Next, NSC were plated on laminin or laminin + CS substrates for 1 and $3 \mathrm{~h}$, followed by fixation, FITC-phalloidin staining, and measurement of cell area (Fig. 3a). At all time points, NSC plated on laminin + CS displayed smaller area in comparison to cells on laminin (Fig. 3b), and the majority of cells remained rounded showing many prominent stress fibers, which is usually associated with inhibited migration. After $18 \mathrm{~h}$, individual NSC spread on laminin and formed clusters on laminin $+\mathrm{CS}$, suggesting that the inhibitory environment induces NSC to migrate along or towards each other and not exhibit exploratory behavior (Fig. 3a). After $18 \mathrm{~h}$, cells were overlapping and it was not possible to define boundaries in order to have an accurate measure.

To evaluate adhesion formation and dynamics, NSC expressing paxillin-GFP were imaged using TIRF microscopy $40 \mathrm{~min}$ after plating on laminin or laminin + CS. Forty percent of the adhesions produced by NSC plated on laminin matured into stable adhesions, and adhesions were productive with active turnover, whereas CS promoted the formation of large elongated and stable adhesions in approximately $57 \%$ of the adhesions near the cell leading edge, and adhesions presented no turnover, assemble and disassemble (Fig. 3c, d and Online Resources 3 and 4). All together, these data suggest that CS induces the production of stable protrusions and adhesions, which inhibits NSC spreading and migration.

\section{RhoA Mediates CS Inhibitory Effects on NSC Migration}

Signals from ECM and soluble factors regulate NSC migration, and most of these signals converge to RhoGTPases which regulate cytoskeleton reorganization and cell migration [6]. Treatment of neurospheres and NSC single cells with Y27632, an inhibitor of ROCK, reversed the inhibitory effects of CS on cell migration, suggesting that CS regulates RhoA/ ROCK signaling pathway (Fig. 4a). Inhibition of ROCK leads to a significant increase in the distance NSC migrate out of the neurosphere ( $p=0.0004$ ) (Fig. 4b). Furthermore, NSC spreading area on laminin + CS substrate was larger in cells treated with ROCK inhibitor than in untreated cells (Fig. 4c, d). After $3 \mathrm{~h}$ of Y27632 treatment, some cells formed two or more protrusions and a long tail, and after $18 \mathrm{~h}$, clusters of NSC plated on laminin + CS were not observed (Fig. 4c). Besides, while $70 \%$ of neurospheres plated on laminin + CS had no cells migrating, addition of Y27632 induced $100 \%$ of the neurospheres to have cells migrating more than $50 \mu \mathrm{m}$ (data not shown). TIRF analyses also revealed that cells plated on laminin + CS in the presence of Y27632 produced significantly smaller adhesions than those produced by untreated cells (Fig. 4e, f and Online Resource 5).

In order to determine if CS regulates RhoA/ROCK signaling pathway during NSC migration, we assessed the activation of RhoA/ROCK using pull-down assay to measure active RhoA (GTP-bound RhoA) 3 after neurospheres were plated on laminin or laminin + CS. RhoA activity was increased in neurosphere-derived cells plated on laminin $+\mathrm{CS}$ for $3 \mathrm{~h}$ (Fig. 5). These results provide additional insight that CS inhibits the initiation of NSC migration in vitro through RhoA/ ROCK activation.

\section{Discussion}

In the adult injured nervous system, components of the glial scar such as CSPG inhibit axon growth and regeneration [33]. The TBI-induced glial scar is a CS-rich environment that prevents SVZ-derived migratory neuroblasts from entering the injured area, reducing the chances for regeneration. Using in vitro experiments, we were able to show that CS acts through $\mathrm{NgR}$ and activates RhoA/ROCK signaling, decreases distance and speed of NSC migration and also induces the formation of large stable adhesions. Inhibition of ROCK allowed NSC migration and reversed CS effects on NSC, suggesting that CS inhibits NSC migration through RhoA/ ROCK activation.

Cell proliferation and migration to the injury site are the initial steps in NSC recruitment to regenerate the injured tissue. Traumas to the CNS such as ischemia or TBI activate astrocytes and oligodendrocytes that, together with infiltrating 
Fig. 3 CS promotes formation of large and elongated adhesions. a, b NSC were plated on laminin or laminin $+\mathrm{CS}$ for 1 and $3 \mathrm{~h}$, fixed, and stained with FITC-phalloidin. CS induced NSC to show a smaller spreading area in comparison to cells plated on laminin. At least 30 cells were measured for each condition in three independent experiments. After $18 \mathrm{~h}$, NSC formed clusters on laminin + CS, whereas cells were isolated when plated on laminin only. Scale bar at $20 \mu \mathrm{m}$. c, d Cells were nucleofected with GFP-paxillin and plated on laminin or laminin $+\mathrm{CS}$, and pictures were captured using TIRF microscope. CS induced formation of larger and elongated adhesions on NSC when compared to laminin $(* * * p=0.0001)$. Scale bar at $6 \mu \mathrm{m}$. Number of adhesions analyzed: laminin $=77 ; \mathrm{CS}=71$ a
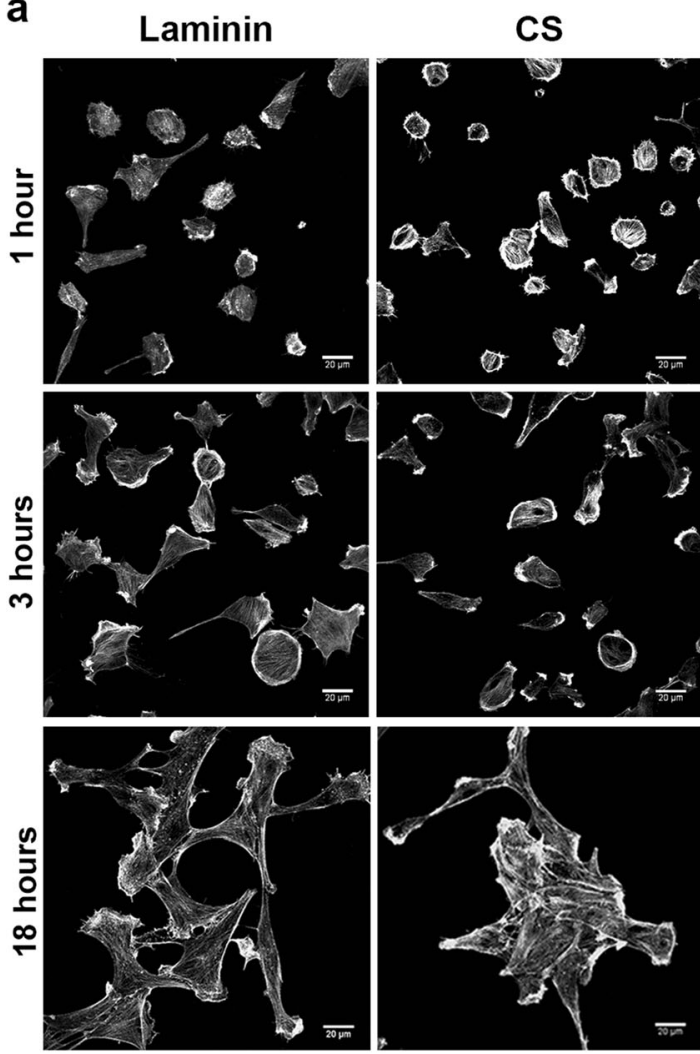

C Laminin
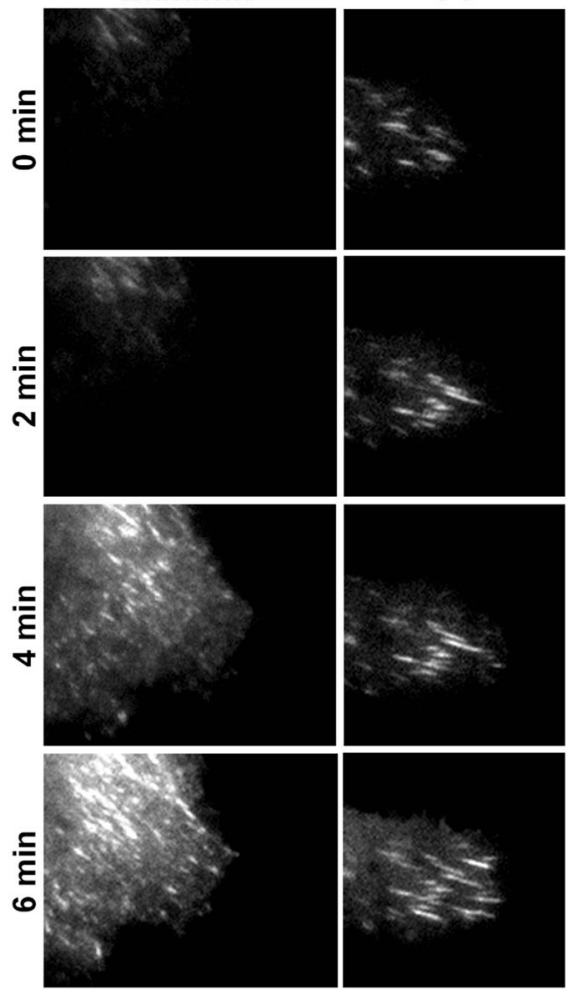

b

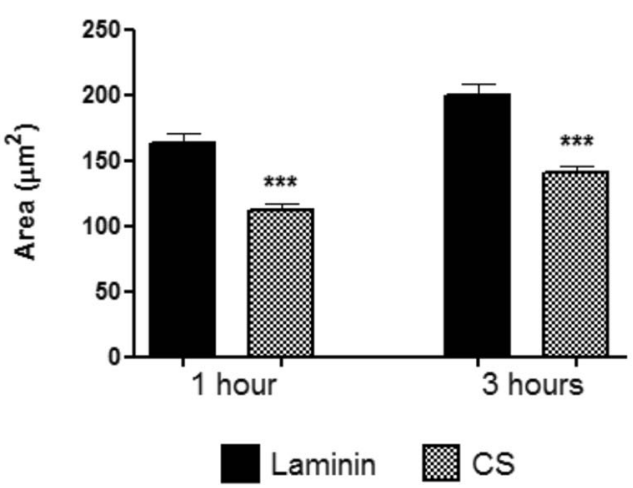

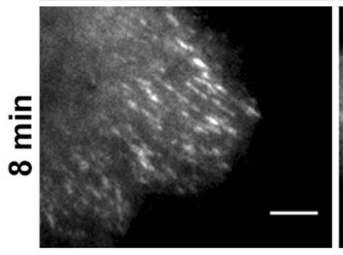
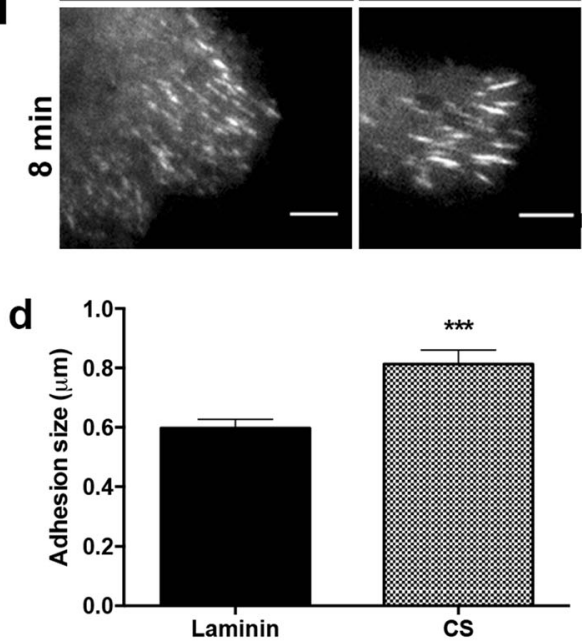

blood cells, express cytokines and chemokines as part of the local inflammatory response. This localized increase in chemokines produces a gradient that attracts NSC from the neurogenic niche localized at the SVZ that migrate towards the injured area [5, 34, 35]. Expression of chemokines and their receptors is upregulated minutes after injury and can last days depending on the severity of the trauma [29].

We investigated neuroblast migration towards TBI 2 weeks postinjury and observed that there is extensive migration of those cells from the SVZ to the lesion site. However, the glial scar composed of OMGp, MAG, Nogo, and CSPG prevents neuroblasts from penetrating the injury $[36,37]$. The glial scar is well characterized as a specific ECM composition that starts to form 7 days post-injury, is accompanied of massive astrogliosis, and prevents axons from entering the lesion as well as causing growth cone collapse due to filopodia retraction [38-40].

Recently, LAR (leukocyte common-antigen related phosphatase) and NgR have been described as CSPG receptors, both expressed by NSC. Dyck et al. [41] showed that knockdown of LAR and RPTP $\sigma$ increases spinal cord NSC attachment, spreading, survival, differentiation, and proliferation on CSPG substrate in vitro. Furthermore, NgR1, NgR3, and RPTP $\sigma$ knockout mice showed enhanced fiber regeneration 
Fig. 4 RhoA/ROCK inhibition promotes NSC migration on CS. a, b NSC migrate significantly longer distances in the presence of $10 \mu \mathrm{M}$ of $\mathrm{Y} 27632$ on laminin + $\mathrm{CS}, 18 \mathrm{~h}$ after plating $(* * * p=0.0004)$. Scale bar at $200 \mu \mathrm{m}$. c, d Inhibition of ROCK increases NSC area 1 and $3 \mathrm{~h}$ after plating on laminin $+\mathrm{CS}$

$(* * * p=0.0001)$. At least 30 cells were measured for each condition in three independent experiments. Eighteen hours after plating, NSC do not form cell clusters on CS in the presence of Y27632, as it was observed without ROCK inhibition. e, f TIRF analyses revealed that adhesions were significantly smaller on cells plated on laminin $+\mathrm{CS}$ in the presence of ROCK inhibitor $(* * p=0.0188)$. Number of adhesions analyzed: $\mathrm{CS}=71$; $\mathrm{CS}+\mathrm{Y} 27632=30$. Scale bar at $6 \mu \mathrm{m}$ a
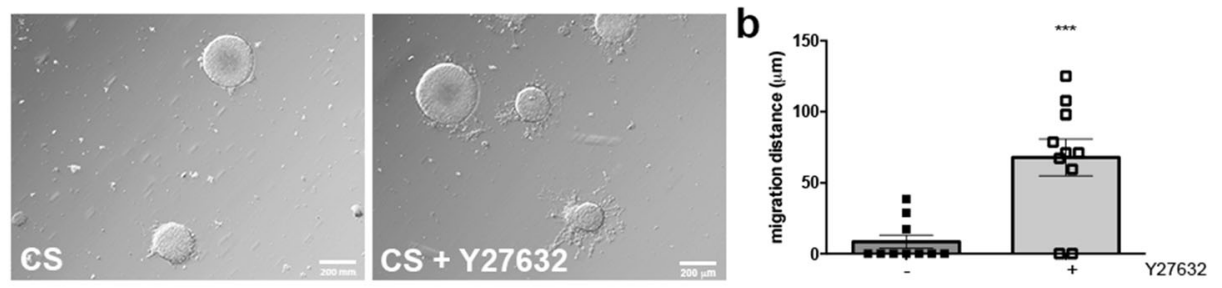

C
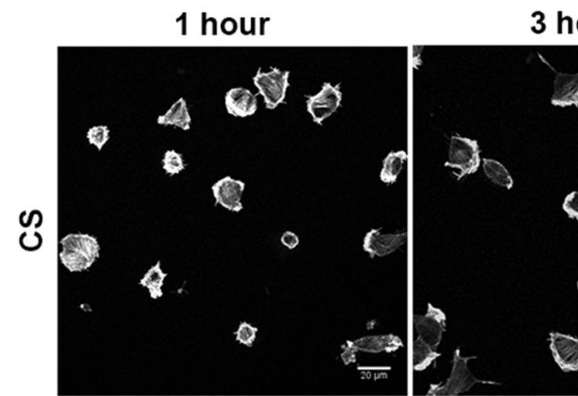

3 hours

18 hours
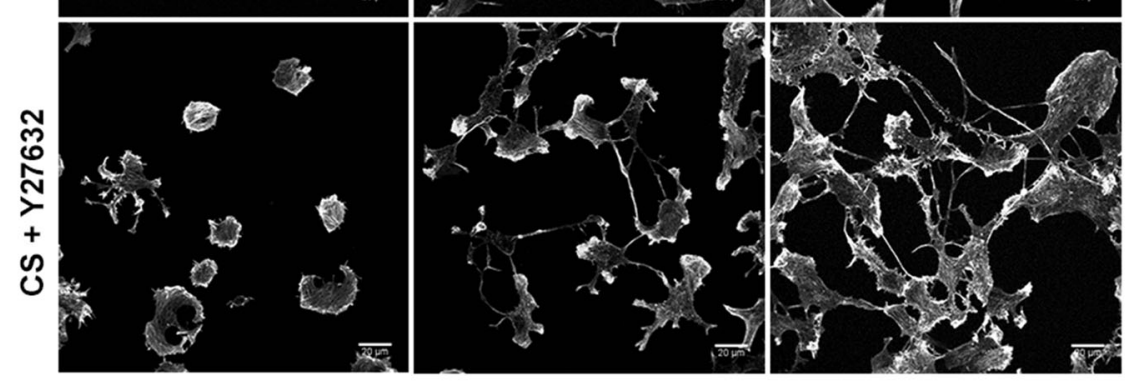

d
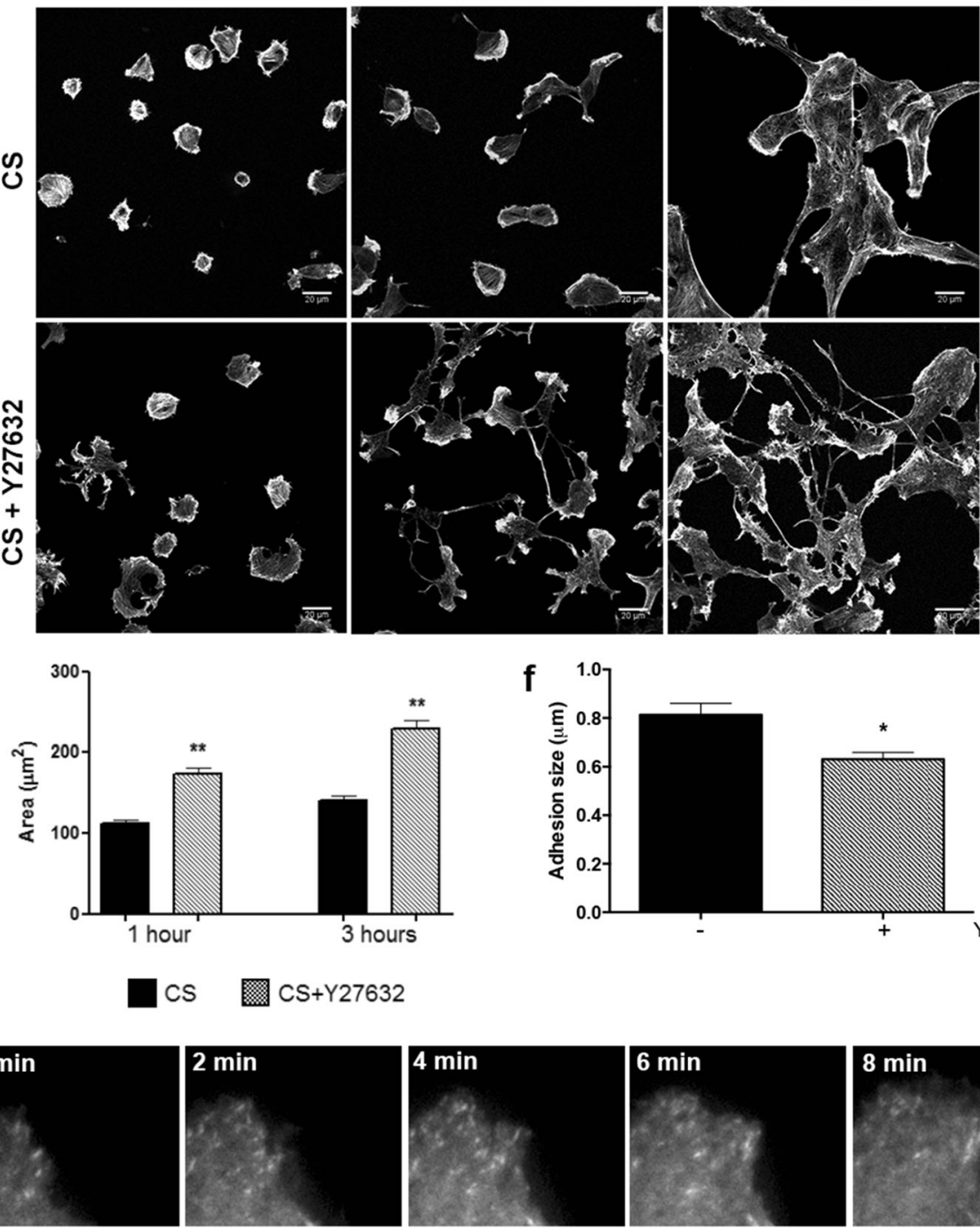

CS+Y27632
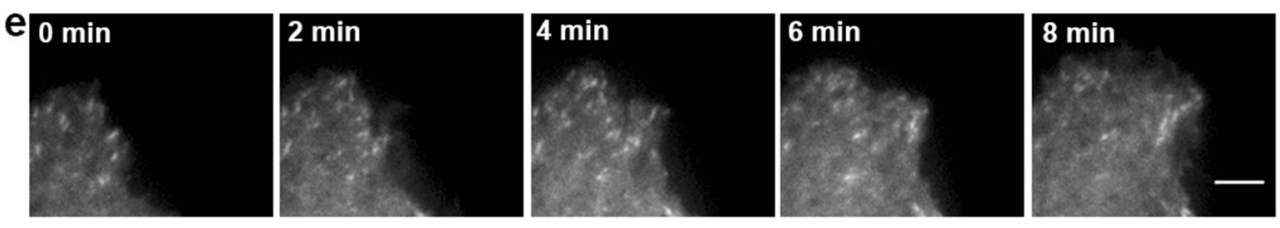

following injury to the optic nerve $[15,19], \mathrm{NgR} 1$ inhibition promoted NSC proliferation and differentiation [42, 43], and mild hypothermia combined with small interfering RNA silencing of NgR gene in NSC promoted NSC axonal outgrowth after SCI in rats [44]. Neurospheres plated on CS substrate in the presence of the $\mathrm{NgR}$ antagonizing peptide NEP1-40 were able to migrate, strongly suggesting that NSC inhibition of migration by CS is mediated by $\mathrm{NgR}$ followed by activation of RhoA/ROCK.

Several studies reported that the CS side chains are responsible for CSPG-mediated inhibition of neurite outgrowth and growth cone collapse, and treatment of neurons with chondroitinase $\mathrm{ABC}$, an enzyme that degrades $\mathrm{CS}$, abrogates the inhibition [12, 14, 45-47]; however, in vivo treatment with chondroitinase $\mathrm{ABC}$ increases significantly the inflammatory response in the injury site [12]. Based on those observations, we investigated the effects of CS on NSC migration in vitro.

Laminin is a glycoprotein that mediates cell adhesion and migration during development and wound healing, and is a permissive environment for NSC migration both in vivo and in vitro. NSC plated on laminin were able to migrate, whereas migration was impaired by the addition of CS. Considering 


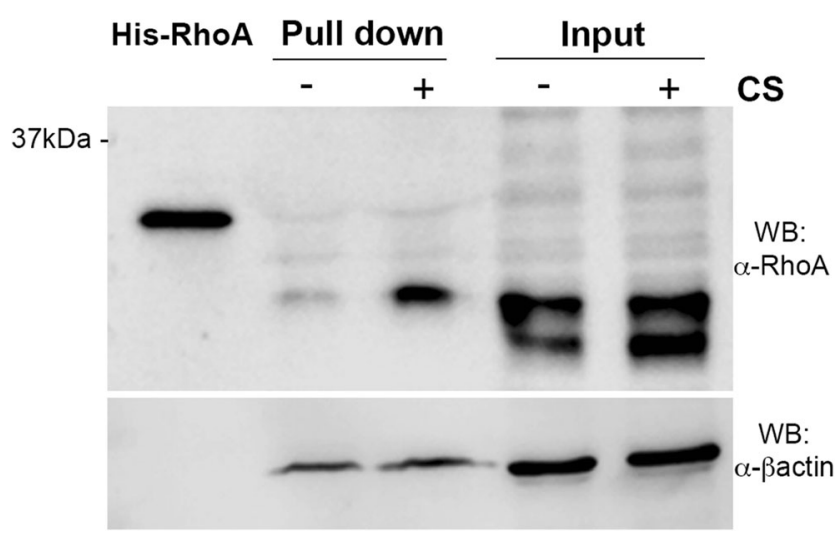

Fig. 5 CS induces RhoA activation. Neurospheres were plated on laminin or laminin $+\mathrm{CS}$ for $3 \mathrm{~h}$, and pull-down assay was performed to assess RhoA activity. Laminin + CS increased RhoA activation within $3 \mathrm{~h}$ after neurospheres were plated. One pull-down experiment was performed in triplicate

that neurospheres behave as a 3-D environment for stem cells only when they are floating, when adhered to the plate cells migrate out of the sphere on a 2D substrate, similar to what happens to the dissociated cells. Although on the first hour, the speed of single cells migrating on CS $(12 \mu \mathrm{m} / \mathrm{h})$ is $60 \%$ of the speed of cells migrating on laminin $(20 \mu \mathrm{m} / \mathrm{h})$, the net traveled distance, measured as a straight line from start to finish, is inhibited by $55 \%$, similar to what we observed for cells migrating away from the neurosphere. Moreover, NSC moved significantly slower during the first hour in the presence of CS, probably due to impairment of protrusion speed and stability, indicating that the inhibitory effect of $\mathrm{CS}$ is relevant for the initiation of the NSC migratory process. These results agree with $\mathrm{Gu}$ et al. [45] who demonstrated that treatment of embryo-derived neurospheres with chondroitinase ABC enhanced NSC migration in vitro.

Cell migration is a multistep process composed of leading edge protrusion, focal adhesion turnover, generation of traction forces, and tail retraction and detachment. NSC plated as single cells were unable to spread on CS surface, keeping a smaller area at all time points analyzed. Protrusion stability indicates that alterations in protrusion dynamics could be related to disturbances in adhesion formation. TIRF time-lapse images showed that CS induced the formation of large, stable adhesions. Assembly and disassembly of adhesions and cell detachment are essential for cell migration, and migration speed also relies on the strength of cell attachment [48-50]. Number and size of adhesions can influence cell migration. This is supported by the observation that fibroblasts lacking protein tyrosine phosphatase have an increased number and size of adhesions, culminating in a migration defect [51]. Our results suggest that as NSC adhesions on CS are larger than those formed on laminin and do not disassemble, cells have difficulty to detach from the CS substrate, hampering cell protrusion and migration.
Rac and $\mathrm{Cdc} 42$ are required at the leading edge, mediating the formation of lamellipodia and filopodia, respectively, whereas Rho and its effector ROCK are required for actin/ myosin stress fibers assembly for adhesion maturation and detachment of the cell rear [21, 52]. The function of Rho/ ROCK at the leading edge is less clear. However, our results suggest that CS induces the activation of RhoA in the initiation of cell migration in vitro, hampering migration process.

Here, we show that inhibition of ROCK significantly stimulated NSC migration on CS. Cells lost the rounded shape and after different periods of time assumed a migratory shape with a leading actin protruded edge, although some cells exhibited several protrusions and long tails, which persisted until the 18th hour. These morphological characteristics are consistent with previous studies, which reported a long cell tail in hematopoietic stem cells, leukocytes, and fibroblasts induced by treatment with ROCK inhibitor Y27632 [53-55]. Unlike what was described in these studies, Y27632 did not lead to impaired cell migration; on the contrary, it has decreased the adhesion sizes and stimulated NSC migration on the inhibitory substrate, partially reverting CS inhibitory effect. Similar results were observed with human keratinocytes that showed increased migration in the presence of Y27632 [56] and murine myofibroblasts $(\mathrm{C} 2 \mathrm{C} 12)$, cells that increased cell migration and speed and significantly reduced the size of adhesions when treated with ROCK inhibitor [57].

Inhibition of RhoA or ROCK leads to neural tissue regeneration after glial scar formation in spinal cord and optic nerve [18, 58]. ROCK inhibitor also enhanced NSC migration in vitro in SVZ explants cultured in Matrigel® [59]. Similar to other inhibitory molecules such as MAIs, CSPG axonal growth inhibitory effect depends on RhoA activation $[19,60]$. Our results corroborate with that, as ROCK inhibition allowed NSC migration on CS.

In conclusion, repair to TBI or to other injuries to the CNS is challenging mainly due to glial scar formation, axonal growth inhibition, and cell survival. NSCderived neuroblast migration to an injured site is an endeavor to repair. Here, we show that neuroblasts migrate towards the injury site but are prevented to enter into the lesion and glial scar rich in CS among other inhibitory molecules. Our in vitro experiments suggest that CS hampers NSC migration due to changes in cell protrusion and adhesion dynamics, which were recovered by inhibition of RhoA/ROCK or modulation of $\mathrm{NgR}$ activation.

\section{Compliance with Ethical Standards}

Funding This work was supported by Fundação de Amparo à Pesquisa de São Paulo - FAPESP (2011/00526-7; 2012/00652 to MP), Conselho Nacional de Desenvolvimento Científico e Tecnológico - $\mathrm{CNPq}$ (404,646/2012-3 to MP), and National Institute of General Medical Sciences (GM23244 to ARH). 
Conflict of Interest The authors declare that there are no conflicts of interest.

Open Access This article is distributed under the terms of the Creative Commons Attribution 4.0 International License (http:// creativecommons.org/licenses/by/4.0/), which permits unrestricted use, distribution, and reproduction in any medium, provided you give appropriate credit to the original author(s) and the source, provide a link to the Creative Commons license, and indicate if changes were made.

\section{References}

1. Lois C, Alvarez-Buylla A (1994) Long-distance neuronal migration in the adult mammalian brain. Science 264(5162):1145-1148

2. Lois C, Garcia-Verdugo JM, Alvarez-Buylla A (1996) Chain migration of neuronal precursors. Science 271(5251):978-981

3. Alvarez-Buylla A, Lim DA (2004) For the long run: maintaining germinal niches in the adult brain. Neuron 41(5):683-686

4. Kojima T, Hirota Y, Ema M, Takahashi S, Miyoshi I, Okano H, Sawamoto K (2010) Subventricular zone-derived neural progenitor cells migrate along a blood vessel scaffold toward the post-stroke striatum. Stem Cells 28(3):545-554. doi:10.1002/stem.306

5. Filippo TR, Galindo LT, Barnabe GF, Ariza CB, Mello LE, Juliano MA, Juliano L, Porcionatto MA (2013) CXCL12 N-terminal end is sufficient to induce chemotaxis and proliferation of neural stem/ progenitor cells. Stem Cell Res 11(2):913-925. doi:10.1016/j.scr. 2013.06.003

6. Leong SY, Turnley AM (2011) Regulation of adult neural precursor cell migration. Neurochem Int 59(3):382-393. doi:10.1016/j. neuint.2010.12.024

7. Busch SA, Silver J (2007) The role of extracellular matrix in CNS regeneration. Curr Opin Neurobiol 17(1):120-127. doi:10.1016/j. conb.2006.09.004

8. Rhodes KE, Fawcett JW (2004) Chondroitin sulphate proteoglycans: preventing plasticity or protecting the CNS? J Anat 204(1): 33-48. doi:10.1111/j.1469-7580.2004.00261.x

9. Kantor DB, Chivatakarn O, Peer KL, Oster SF, Inatani M, Hansen MJ, Flanagan JG, Yamaguchi Y et al (2004) Semaphorin 5A is a bifunctional axon guidance cue regulated by heparan and chondroitin sulfate proteoglycans. Neuron 44(6):961-975. doi:10.1016/j. neuron.2004.12.002

10. Siebert JR, Conta Steencken A, Osterhout DJ (2014) Chondroitin sulfate proteoglycans in the nervous system: inhibitors to repair. Biomed Res Int 2014:845323. doi:10.1155/2014/845323

11. Tanaka M, Maeda N, Noda M, Marunouchi T (2003) A chondroitin sulfate proteoglycan PTPzeta /RPTPbeta regulates the morphogenesis of Purkinje cell dendrites in the developing cerebellum. J Neurosci 23(7):2804-2814

12. Coulson-Thomas YM, Coulson-Thomas VJ, Filippo TR, Mortara RA, da Silveira RB, Nader HB, Porcionatto MA (2008) Adult bone marrow-derived mononuclear cells expressing chondroitinase AC transplanted into CNS injury sites promote local brain chondroitin sulphate degradation. J Neurosci Methods 171(1):19-29. doi:10. 1016/j.jneumeth.2008.01.030

13. Lin R, Kwok JC, Crespo D, Fawcett JW (2008) Chondroitinase $\mathrm{ABC}$ has a long-lasting effect on chondroitin sulphate glycosaminoglycan content in the injured rat brain. J Neurochem 104(2):400408. doi:10.1111/j.1471-4159.2007.05066.x

14. Bartus K, James ND, Didangelos A, Bosch KD, Verhaagen J, Yanez-Munoz RJ, Rogers JH, Schneider BL et al (2014) Largescale chondroitin sulfate proteoglycan digestion with chondroitinase gene therapy leads to reduced pathology and modulates macrophage phenotype following spinal cord contusion injury. J Neurosci 34(14):4822-4836. doi:10.1523/JNEUROSCI. 4369-13.2014

15. Dickendesher TL, Baldwin KT, Mironova YA, Koriyama Y, Raiker SJ, Askew KL, Wood A, Geoffroy CG et al (2012) NgR1 and NgR3 are receptors for chondroitin sulfate proteoglycans. Nat Neurosci. doi:10.1038/nn.3070

16. Shen Y, Tenney AP, Busch SA, Horn KP, Cuascut FX, Liu K, He Z, Silver J et al (2009) PTPsigma is a receptor for chondroitin sulfate proteoglycan, an inhibitor of neural regeneration. Science 326(5952):592-596. doi:10.1126/science. 1178310

17. Fry EJ, Chagnon MJ, Lopez-Vales R, Tremblay ML, David S (2010) Corticospinal tract regeneration after spinal cord injury in receptor protein tyrosine phosphatase sigma deficient mice. Glia 58(4):423-433. doi:10.1002/glia.20934

18. Monnier PP, Sierra A, Schwab JM, Henke-Fahle S, Mueller BK (2003) The Rho/ROCK pathway mediates neurite growthinhibitory activity associated with the chondroitin sulfate proteoglycans of the CNS glial scar. Mol Cell Neurosci 22(3):319-330

19. Fisher D, Xing B, Dill J, Li H, Hoang HH, Zhao Z, Yang XL, Bachoo R et al (2011) Leukocyte common antigen-related phosphatase is a functional receptor for chondroitin sulfate proteoglycan axon growth inhibitors. J Neurosci 31(40):14051-14066. doi:10. 1523/JNEUROSCI.1737-11.2011

20. Vicente-Manzanares M, Newell-Litwa K, Bachir AI, Whitmore LA, Horwitz AR (2011) Myosin IIA/IIB restrict adhesive and protrusive signaling to generate front-back polarity in migrating cells. J Cell Biol 193(2):381-396. doi:10.1083/jcb.201012159

21. Parsons JT, Horwitz AR, Schwartz MA (2010) Cell adhesion: integrating cytoskeletal dynamics and cellular tension. Nat Rev Mol Cell Biol 11(9):633-643. doi:10.1038/nrm2957

22. Bradbury EJ, Moon LD, Popat RJ, King VR, Bennett GS, Patel PN, Fawcett JW, McMahon SB (2002) Chondroitinase ABC promotes functional recovery after spinal cord injury. Nature 416(6881):636640. doi:10.1038/416636a

23. Chiba S, Ikeda R, Kurokawa MS, Yoshikawa H, Takeno M, Nagafuchi H, Tadokoro M, Sekino H et al (2004) Anatomical and functional recovery by embryonic stem cell-derived neural tissue of a mouse model of brain damage. J Neurol Sci 219(1-2):107-117. doi:10.1016/j.jns.2004.01.006S0022510X04000152

24. Paxinos G, Franklin K (2001) The mouse brain in stereotaxic coordinates. 2 edn. Academic Press, USA

25. Galindo LT, Filippo TR, Semedo P, Ariza CB, Moreira CM, Camara NO, Porcionatto MA (2011) Mesenchymal stem cell therapy modulates the inflammatory response in experimental traumatic brain injury. Neurol Res Int 2011:564089. doi:10. $1155 / 2011 / 564089$

26. Siebzehnrubl FA, Vedam-Mai V, Azari H, Reynolds BA, Deleyrolle LP (2011) Isolation and characterization of adult neural stem cells. Methods Mol Biol 750:61-77. doi:10.1007/978-1-61779-145-1 4

27. Webb DJ, Donais K, Whitmore LA, Thomas SM, Turner $\overline{C E}$, Parsons JT, Horwitz AF (2004) FAK-Src signalling through paxillin, ERK and MLCK regulates adhesion disassembly. Nat Cell Biol 6(2):154-161. doi:10.1038/ncb1094

28. Hinz B, Alt W, Johnen C, Herzog V, Kaiser HW (1999) Quantifying lamella dynamics of cultured cells by SACED, a new computer-assisted motion analysis. Exp Cell Res 251(1): 234-243. doi:10.1006/excr.1999.4541

29. Jaerve A, Muller HW (2012) Chemokines in CNS injury and repair. Cell Tissue Res 349(1):229-248. doi:10.1007/s00441-012-1427-3

30. Takeuchi H, Natsume A, Wakabayashi T, Aoshima C, Shimato S, Ito M, Ishii J, Maeda Y et al (2007) Intravenously transplanted human neural stem cells migrate to the injured spinal cord in adult mice in an SDF-1- and HGF-dependent manner. Neurosci Lett 426(2):69-74. doi:10.1016/j.neulet.2007.08.048

31. Akbik F, Cafferty WB, Strittmatter SM (2012) Myelin associated inhibitors: a link between injury-induced and experience-dependent 
plasticity. Exp Neurol 235(1):43-52. doi:10.1016/j.expneurol. 2011.06.006

32. Llorens F, Gil V, del Rio JA (2011) Emerging functions of myelin-associated proteins during development, neuronal plasticity, and neurodegeneration. FASEB J 25(2):463-475. doi:10.1096/fj.10-162792

33. Galtrey CM, Fawcett JW (2007) The role of chondroitin sulfate proteoglycans in regeneration and plasticity in the central nervous system. Brain Res Rev 54(1):1-18. doi:10.1016/j.brainresrev.2006. 09.006

34. Yan YP, Sailor KA, Lang BT, Park SW, Vemuganti R, Dempsey RJ (2007) Monocyte chemoattractant protein-1 plays a critical role in neuroblast migration after focal cerebral ischemia. J Cereb Blood Flow Metab 27(6):1213-1224. doi:10.1038/sj.jcbfm.9600432

35. Robin AM, Zhang ZG, Wang L, Zhang RL, Katakowski M, Zhang L, Wang Y, Zhang C et al (2006) Stromal cell-derived factor 1alpha mediates neural progenitor cell motility after focal cerebral ischemia. J Cereb Blood Flow Metab 26(1):125-134. doi:10.1038/sj. jcbfm.9600172

36. Garwood J, Heck N, Reichardt F, Faissner A (2003) Phosphacan short isoform, a novel non-proteoglycan variant of phosphacan/ receptor protein tyrosine phosphatase-beta, interacts with neuronal receptors and promotes neurite outgrowth. J Biol Chem 278(26): 24164-24173. doi:10.1074/jbc.M211721200

37. Garwood J, Schnadelbach O, Clement A, Schutte K, Bach A, Faissner A (1999) DSD-1-proteoglycan is the mouse homolog of phosphacan and displays opposing effects on neurite outgrowth dependent on neuronal lineage. J Neurosci 19(10):3888-3899

38. Carulli D, Laabs T, Geller HM, Fawcett JW (2005) Chondroitin sulfate proteoglycans in neural development and regeneration. Curr Opin Neurobiol 15(1):116-120. doi: 10.1016/j.conb.2005.01.014

39. Silver J, Miller JH (2004) Regeneration beyond the glial scar. Nat Rev Neurosci 5(2):146-156. doi:10.1038/nrn1326

40. Villapol S, Byrnes KR, Symes AJ (2014) Temporal dynamics of cerebral blood flow, cortical damage, apoptosis, astrocytevasculature interaction and astrogliosis in the pericontusional region after traumatic brain injury. Front Neurol 5:82. doi:10.3389/fneur. 2014.00082

41. Dyck SM, Alizadeh A, Santhosh KT, Proulx EH, Wu CL, KarimiAbdolrezaee S (2015) Chondroitin sulfate proteoglycans negatively modulate spinal cord neural precursor cells by signaling through LAR and RPTPsigma and modulation of the Rho/ROCK pathway. Stem Cells. doi:10.1002/stem.1979

42. Wang F, Zhu Y (2008) The interaction of Nogo-66 receptor with Nogo-p4 inhibits the neuronal differentiation of neural stem cells. Neuroscience 151(1):74-81. doi:10.1016/j. neuroscience.2007.10.034

43. Li X, Su H, Fu QL, Guo J, Lee DH, So KF, Wu W (2011) Soluble $\mathrm{NgR}$ fusion protein modulates the proliferation of neural progenitor cells via the Notch pathway. Neurochem Res 36(12):2363-2372. doi:10.1007/s11064-011-0562-7

44. Wang D, Liang J, Zhang J, Liu S, Sun W (2014) Mild hypothermia combined with a scaffold of NgR-silenced neural stem cells/ Schwann cells to treat spinal cord injury. Neural Regen Res 9(24): 2189-2196. doi:10.4103/1673-5374.147952

45. Gu WL, Fu SL, Wang YX, Li Y, Lu HZ, Xu XM, Lu PH (2009) Chondroitin sulfate proteoglycans regulate the growth, differentiation and migration of multipotent neural precursor cells through the integrin signaling pathway. BMC Neurosci 10:128. doi:10.1186/ 1471-2202-10-128
46. Houle JD, Tom VJ, Mayes D, Wagoner G, Phillips N, Silver J (2006) Combining an autologous peripheral nervous system "bridge" and matrix modification by chondroitinase allows robust, functional regeneration beyond a hemisection lesion of the adult rat spinal cord. J Neurosci 26(28):7405-7415. doi:10.1523/ JNEUROSCI.1166-06.2006

47. Garcia-Alias G, Barkhuysen S, Buckle M, Fawcett JW (2009) Chondroitinase $\mathrm{ABC}$ treatment opens a window of opportunity for task-specific rehabilitation. Nat Neurosci 12(9):1145-1151. doi:10.1038/nn.2377

48. Ridley AJ, Schwartz MA, Burridge K, Firtel RA, Ginsberg MH, Borisy G, Parsons JT, Horwitz AR (2003) Cell migration: integrating signals from front to back. Science 302(5651):1704-1709. doi: 10.1126/science. 1092053302/5651/1704

49. Webb DJ, Parsons JT, Horwitz AF (2002) Adhesion assembly, disassembly and turnover in migrating cells - over and over and over again. Nat Cell Biol 4(4):E97-100. doi:10.1038/ncb0402-e97

50. Ayoub E, Hall A, Scott AM, Chagnon MJ, Miquel G, Halle M, Noda M, Bikfalvi A et al (2013) Regulation of the Src kinaseassociated phosphoprotein 55 homologue by the protein tyrosine phosphatase PTP-PEST in the control of cell motility. J Biol Chem 288(36):25739-25748. doi:10.1074/jbc.M113.501007

51. Angers-Loustau A, Cote JF, Charest A, Dowbenko D, Spencer S, Lasky LA, Tremblay ML (1999) Protein tyrosine phosphatasePEST regulates focal adhesion disassembly, migration, and cytokinesis in fibroblasts. J Cell Biol 144(5):1019-1031

52. Rottner K, Hall A, Small JV (1999) Interplay between Rac and Rho in the control of substrate contact dynamics. Curr Biol : CB 9(12): 640-648

53. Fonseca AV, Freund D, Bornhauser M, Corbeil D (2010) Polarization and migration of hematopoietic stem and progenitor cells rely on the RhoA/ROCK I pathway and an active reorganization of the microtubule network. J Biol Chem 285(41):3166131671. doi:10.1074/jbc.M110.145037

54. Smith A, Bracke M, Leitinger B, Porter JC, Hogg N (2003) LFA-1induced T cell migration on ICAM-1 involves regulation of MLCKmediated attachment and ROCK-dependent detachment. J Cell Sci 116(Pt 15):3123-3133. doi:10.1242/jcs.00606

55. Zhou C, Petroll WM (2010) Rho kinase regulation of fibroblast migratory mechanics in fibrillar collagen matrices. Cell Mol Bioeng 3(1):76-83. doi:10.1007/s12195-010-0106-2

56. Gandham VD, Maddala RL, Rao V, Jin JY, Epstein DL, Hall RP, Zhang JY (2013) Effects of Y27632 on keratinocyte procurement and wound healing. Clin Exp Dermatol 38(7):782-786. doi:10. 1111/ced.12067

57. Goetsch KP, Snyman C, Myburgh KH, Niesler CU (2014) ROCK-2 is associated with focal adhesion maturation during myoblast migration. J Cell Biochem 115(7):1299-1307. doi:10.1002/jcb.24784

58. Fournier AE, Takizawa BT, Strittmatter SM (2003) Rho kinase inhibition enhances axonal regeneration in the injured CNS. J Neurosci 23(4):1416-1423

59. Leong SY, Faux CH, Turbic A, Dixon KJ, Turnley AM (2011) The Rho kinase pathway regulates mouse adult neural precursor cell migration. Stem Cells 29(2):332-343. doi:10.1002/stem.577

60. Schweigreiter R, Walmsley AR, Niederost B, Zimmermann DR, Oertle T, Casademunt E, Frentzel S, Dechant G et al (2004) Versican V2 and the central inhibitory domain of Nogo-A inhibit neurite growth via $\mathrm{p} 75 \mathrm{NTR} / \mathrm{NgR}$-independent pathways that converge at RhoA. Mol Cell Neurosci 27(2):163-174. doi:10.1016/j. men.2004.06.004 